studies on psychosocial aspects of prenatal diagnosis.

\section{DEFECTIVE PROCESSING OF LYSOSOMAL ENZYMES}

Kurt von Figura, Andrej Hasilik, Regina Pohlmann, Peter Lemansky and Thomas Braulke

Physiologisch-Chemisches Institut, University of Münster, D-4400 Münster, FRG

Lysosomal enzymes are synthesized at the rough endoplasmic reticulum as glycosylatedprecursors of high molecular weight. In the endoplasmic reticulum and following in the Golgi complex they undergo a series of modifications that involve cleavage of the aminoterminal signal peptide, disulfide binding, oligosaccharide processing and subunit association. Mannose 6-phosphate residues added in the Golgi complex serve as a signal for recognition by mannose 6-phosphate specific receptors. The receptorligand complexes are routed to a prelysosomal acidic compartment, where the lysosomal enzymes and receptors dissociate. The receptors return to the site, where they bind lysosomal enzymes (within or distal to the trans-Golgi). A second mannose 6-phosphate receptor dependent pathway ensures receptor-mediated endocytosis of (exogenous) lysosomal enzymes. The pathways for receptor-mediated transport of endogenous and exogenous lysosomal enzymes are connected and both involve clathrin-coated vesicles. The lysosomal enzymes released from the receptors are transported to lysosomes, where they undergo a limited proteolysis, termed maturation. It has become apparent that defective activity of a lysosomal enzyme in a lysosomal storage disease can be caused by one of the following reasons: 1 . Defective synthesis of the lysosomal enzyme polypeptide. 2. Defective transport of the newly synthesized lysosomal enzyme to lysosomes. 3. Instability of the lysosomal enzyme polypeptide within the lysosomes. 4. Deficiency in a cofactor required for activation of the lysosomal enzyme or for presenting the substrate. 5. Synthesis of a catalytically inactive lysosomal enzyme polypeptide. A single mutation may affect several of these parameters, e.g. catalytic activity and stability or transport properties and stability. The lysosomal storage disorders in which different mutations have been identified by studying the biosynthesis and processing of lysosomal enzymes comprise the following disorders: M. Tay-Sachs $(1,2)$, Pompe $(3,4)$, fucosidosis $(5)$, metachromatic leukodystrophy (6), Gaucher (7), Fabry (8) and Maroteaux-Lamy (9). The analysis of the molecular defects in lysosomal storage disorders using the recently cloned cDNAs for lysosomal enzymes will provide an increased understanding of the requirements for synthesis, processing, stability and transport of lysosomal enzymes under normal conditions.

\section{References:}

1. Proia RL and Neufeld EF 1982 Proc Natl Acad Sci U.S.A. 79: 6360

2. d'Azzo A, Proia RL, Kolodny EH, Kaback MM and Neufeld EF $1984 \mathrm{~J}$ Biol Chem 259: 11070

3. Steckel F, Gieselmann V, Waheed A, Hasilik A, von Figura K, Elferink RO, Kalsbeek $R$ and Tager JM 1982 FEBS Lett 150: 69

4. Reuser AJJ, Kroos M, Oude Elferink RPJ and Tager JM 1985 J Biol Chem 260: 8336

5. Johnson $K$ and Dawson G 1985 Biochem Biophys Res Commun 133: 90

6. von Figura K, Steckel $F$ and Hasilik A 1983 Proc Natl Acad Sci U.S.A. 80: 6066
7. Ginns EI, Brady RO, Pirruccello S, Moore C, Sorrell $\mathrm{S}$, Furbish FS, Murray GJ, Tager $\mathrm{J}$ and Barranger JA 1982 Proc Natl Acad Sci U.S.A. 79: 5607

8. Lemansky P, Bishop DF, Desnick RJ, Hasilik A and von Figura K $1986 \mathrm{~J}$ Biol Chem submitted

9. Conary J, Beck M, Hasilik $A$ and von Figura $K$ (unpublished)

BONE MARROW TRANSPLANTATION FOR THE TREATMENT OF LYSOSOMAL STORAGE DISEASES

Kenneth Hugh-Jones

Westminster Childrens Hospital, London, Great-Britain

Replacement treatment by the use of pure enzymes in various lysosomal storage diseases (LSD) has as yet not produced permanent clinical improvement. Brady et al have attempted this in both Gaucher's disease (1) and Niemann-Pick Disease (2) using enzyme made from human placenta. Neither has implantation of fibroblasts (3) or amnion-epithelial cells (4) given any beneficial effects.

In this paper evidence will be produced to show that a successful bone marrow transplantation (BMT) can produce an everlasting source of enzyme. When the missing enzyme can be demonstrated in the white cells, and that this treatment can be clinically effective.

In Wolman's Disease a satisfactory graft resulted in an adequate level of acid esterase and acid lipase both in the white cells and in liver biopsy along with mobilisation and disappearance of cholesterol from the liver (5).

In GM gangliosidosis a stable white cell engraftment led to the disappearance of the hepatosplenomegaly but there was no improvement in the neurological regression, so that the patient died fourteen months after the graft, thus not altering the natural history of the disease (6).

In Niemann-Pick Disease type B (non-neurological) a successful graft has led to some diminution in the stored sphingomyelin within 80 days of BMT. Hopefully the adequate engraftment of normal marrow will continue to produce a normal white cell level of the missing enzyme, sphingomyelinase, which will lead to the disappearance of the hepatosplenomegaly in time, as has occurred in all other cases of LSD so far transplanted.

Five cases of Gaucher's Disease have been successfully engrafted with complete resolution of the hepatosplenomegaly, clearing of the lung infiltrate and slow improvement in the radiological appearances of the bones, clinically a very satisfactory result (7).

The results in the mucopolysaccharidoses (MPS) seem to very in the different types. In all the hepatosplenomegaly resolved, if there is corneal clouding this improves, there is improvement in the cardiac signs if there is evidence of cardiac involvement. Similarly joint mobility improves but there have been very differing results so far as the CNS involvement is concerned.

Six consecutive cases of Hurler's Disease (MPS I) have all shown that the expected regression in intellectual performance has not occurred, three to six years (average 4.6 years) after the graft and three children are already in normal schools. But the evaluable cases of Hunter's Disease (MPS II) continue to regress. Similarly twins transplanted for San fillipo-B Disease (MPS IIIB) are not deteriorating nearly five years after grafting, but one child with San fillipo-A (MPS IIIA) is. (8). Although all these 
children have continued to grow satisfactorily their anatomical bony abnormalities if present, (as in MPS I, II, IV and VI) have not improved after grafting. Thus children with Morquio Disease (MPS IV) (9) and Maroteaux-Lamy Disease (MPS VI) (10) have a disappointing result following BMT, although at first one might have thought they would have been ideal for this treatment, as they have no neurological involvement. There are case reports in the literature of about another thirty inborn errors of metabolism that have been successfully corrected by bone marrow transplantation. (11)

References:

1. Brady RO, Molecular Basis of lysosomal storage diseases, Academic Press Inc 1984, p 461

2. Brady RO, Barranger JA, Gal AE et al Lysosomes and Lysosomal storage diseases, New York, Raven 1980, p 373

3. Gibbs DA, Spellacy E, Thompkins R et al Journal of Inherited Metabolic Diseases 1983, 6:62

4. Adinolfi M, Brown S, Developmental Med and Child Neurol 1984 p 401

5. Hobbs JR, Hugh-Jones K, Shaw PJ et al 1986 Bone Marrow Transplantation Suppl I p 347

6. Shaw PJ, Hugh-Jones K, Hobbs JR et al 1986 Bone Marrow Transplantation Suppl I p 339

7. Shaw PJ, Hugh-Jones K, Hobbs JR et al 1986 Bone Marrow Transplantation Suppl I p 341

8. Shaw PJ, Hugh-Jones K, Hobbs JR et al 1986 Bone Marrow Transplantation Suppl I p 342

9. Desai S, Hobbs JR, Hugh-Jones $\mathrm{K}$ et al 1983 Exp Hematol 11 (Suppl 13) p 98

10. Krivit $\mathrm{W}$, Pierpoint ME, Ayak $\mathrm{K}$ et al $\mathrm{N}$ Engl $\mathrm{J}$ Med 1984,311: p 1606

11. Hobbs JR 1985 Plasma Ther Transfus Technol $6: 221$

DNA ANALYSIS AND THE DIAGNOSIS OF INHERITED DISEASE Robert Williamson

St Mary's Hospital, Medical School, University of London, England

The availability of human DNA sequences in recombinants has transformed human genetics. There are now approximately five hundred coding gene sequences, and innumerable localised anonymous probes, cloned and available pure and in unlimited amount. These can be used by clinical molecular pathologists to study genes in a person-specific way, since anycloned gene sequence is unique to the person from whom it is isolated. Therefore, all of the heritable parameters of individuality, whether representing pathological or normal variation, can be studied by comparing gene sequences.

Many of the cloned human coding genes which have been isolated and characterised to date are also involved in single gene pathology. These include the sequences known to be mutated so as to cause known and characterised Mendelian disorders, such as thalas saemia, PKU or haemophilia. In such cases, the underlying molecular nature of the defect can be determined, and the probe can be used for population-base carrier testing and for unequivocal prenatal diagnosis. Other common single gene defects of unknown biochemistry, such as cystic fibrosis and Duchenne muscular dystrophy, have been linked either to known DNA coding sequences, or to anonymous DNA probes which are chromosomally localised. In these cases, carrier detection and prenatal (or presymptomatic) diagnosis is only available to informative families with living affected members.

A complete map of the human genome will soon be available, which will simplify the task of determining which gene is mutated and the reason why each causes a characteristic pathology. This is particularly true for those diseases which are locus-heterogeneous, or where more than one gene is involved jointly. Conditions such as coronary artery disease, diabetes and hypertension will be obvious candidates for mapping studies, if accurately diagnosed families of sufficient size are available. For the application of these data, however, it will also be necessary to develop new and inexpensive diagnostic methods for rapid gene analysis using small human tissue samples if these developments are to be applied in communitywide clinical practice.

\section{ONCOGENES AND ANTI-ONCOGENES}

Dirk Bootsma

Department of Cell Biology and Genetics, Erasmus

University, Rotterdam

At least two classes of genes have been identified, which are important in the pathogenesis of cancer. The first class was originally discovered by the work on acutely transforming RNA tumor viruses and consists of the oncogenes. Activation of these genes by mutation, chromosome translocation or by other means, provides an essential step in the multistage process of malignant transformation. The second class which includes the socalled anti-oncogenes, has been identified in studies of hereditary cancers, in particular Wilms' tumor and retinoblastoma. Whereas oncogenes behave dominantly (one activated copy is sufficient for producing cancer), the antioncogenes show a recessive mode of cancer initiation both alleles have to be inactivated.

An example of the first class is the abelson oncogene (c-abl) which seems to play an essential role in chronic myeloid leukemia (CML). CML is characterized by the presence of the Philadelphia ( $\mathrm{Ph}^{1}$ ) chromosome in the leukemic cells of 968 of all CML patients. The $\mathrm{Ph}^{1}$ chromosome (22q-) is the result of a reciprocal translocation between chromosome 22 and chromosome 9, t(9q34,22ql1). Previously we described the localization of the human c-abl oncogene on chromosome 9 and demonstrated its translocation to the $\mathrm{Ph}^{1}$ chromosome in $\mathrm{CML}$ patients (1). The cloning and analysis of breakpoint fragments revealed that the breakpoints on chromosome 22 all cluster in a very limited area, the breakpoint cluster region, bcr (2). Breakpoints on chromosome 9, however, are scattered over a large area. The detection of a chimeric mRNA ( $5^{\circ} \mathrm{bcr}$ and $3^{-} \mathrm{abl}$ sequences) in the leukemic cells of CML patients $(3,4)$ and the cloning of chimeric cDNAs from a CML derived cell line K562 $(5,6)$ strongly indicate that bcr and c-abl coding sequences are linked by RNA splicing, independent, from the distance between the two genes on the $\mathrm{Ph}^{1}$ chromosome. These findings suggest an important role for the altered $\mathrm{c}-\mathrm{abl}$ product in the generation and/ or maintenance of CML.

Strong evidence for the existence of the second class of genes the socalled anti-oncogenes comes from studies of Wilms' tumor and retinoblastoma. Both tumors seem to be the result of loss or inactivation of the two alleles of a wild type gene located on Ilpl3 in the case of Wilms' tumor (7) and $13 \mathrm{q} 14$ in retinoblastoma (8). In the herelitary form of these tumors the first inactivation event is present in the germ line as a mutation or chromosome deletion, whereas in the non-hereditary cases (mostly unilaterally affected) the first inactivation event occurs in the somatic cell. As a result of a 